\title{
Increase in the biomass of some green algae species in nitrate and ammonium mediums depending on auto-, mixo- or heterotrophic conditions
}

\author{
STEFAN GUMINSKI, KRYSTYNA JURAJDA, EWA TATKOWSKA
}

Department of Plant Physioiogy, Institute of Botany, Wrockaw University, Kanonia 6/8, 50-328 Wrocław, Poland

(Rcceived March 26. 1984, Accepted: May 29, 1984)

\begin{abstract}
The increase in total dry mass and protein in cultures of Chlorella pyrenoidosa, Scenedesmus quadricauda and Ankistrodesmus acicularis was studied. Under autotrophic conditions, increases in dry mass were, as a rule, larger in the nitrate medium than in the ammonium one, under mixotrophic conditions the situation was reversed and in the case of heterotrophy, the individual species reacted differently. The dependence of the protein content increase on the nitrate or ammonium form of the medium was not clear. Changes in time of the $\mathrm{pH}$ and $\mathrm{rH}$ of the mediums were followed and the interdependence of these changes with the production of biomass is discussed.
\end{abstract}

Key werds: algae, nitrates, ammonium salts, redox potential

INTRODUCTION

In an earlier paper (Gumiński et al. 1983) on the effect of reducing or oxidizing agents on the increase of biomass in the same species of green algae as studied in this paper, we presented, among others, differences in their growth in nitrate and ammonium mediums. These were experiments conducted under constant illumination and exclusively on mineral mediums; under those conditions, all of the studied species grew better in the nitrate than in the ammonium medium.

The utilization of $\mathrm{NO}_{3}{ }^{-}$and $\mathrm{NH}_{4}{ }^{+}$ions by algae has been studied by relatively long ago by a large number of physiologists, and a discussion of their results can be found in the compendious works by Syrett (1962) and Morris (1974). However, comparative studies on the effectivity of these ions under auto-, mixo- and heterotrophic conditions have not been carried 
out and the problem of redox potential changes during culture has been overlooked. These topics have become the subject of the study done presently by determining dry mass and protein.

\section{MATERIAL AND METHODS}

The experiments were done on pure cultures of Chlorella pyrenoidosa, Scenedesmus quadricauda and Ankistrodesmus acicularis; material from these cultures was also used in previous studies (Gumiński et al. 1983).

In the experiments, Uspenski's nitrate medium (1927) and its ammonium varisty worked out by us (Table 1) were used.

Table 1

Nutrient composition in $\mathrm{g} \cdot \mathrm{dm}^{-3}$

\begin{tabular}{|l|c|c|}
\hline \multicolumn{1}{|c|}{ Compound } & Nitrate medium & $\begin{array}{c}\text { Ammonium } \\
\text { medium }\end{array}$ \\
\hline $\mathrm{Ca}\left(\mathrm{NO}_{3}\right)_{2} \cdot 4 \mathrm{H}_{2} \mathrm{O}$ & 0.207 & - \\
$\mathrm{KNO}_{3}$ & 0.025 & - \\
$\mathrm{KH}_{2} \mathrm{PO}_{4}$ & 0.025 & 0.025 \\
$\mathrm{MgSO}_{4} \cdot 7 \mathrm{H}_{2} \mathrm{O}$ & 0.050 & 0.050 \\
$\mathrm{~K}_{2} \mathrm{CO}_{3}$ & 0.035 & 0.069 \\
$\mathrm{CaCO}_{3}$ & - & 0.087 \\
$\mathrm{Fe}_{2}\left(\mathrm{SO}_{4}\right)_{3}$ & 0.002 & 0.002 \\
$\left(\mathrm{NH}_{4}\right)_{2} \mathrm{SO}_{4}$ & - & 0.132 \\
\hline
\end{tabular}

Both mediums also contained microelements in the following amounts $\left(\mathrm{mg}\right.$ per $\left.\mathrm{dm}^{3}\right): \mathrm{H}_{3} \mathrm{BO}_{3}-0.6, \mathrm{MnCl}_{2} \cdot 4 \mathrm{H}_{2} \mathrm{O}-0.4, \mathrm{ZnSO}_{4} \cdot 7 \mathrm{H}_{2} \mathrm{O}-0.05$, $\mathrm{CuSO}_{4} \cdot 5 \mathrm{H}_{2} \mathrm{O}-0.05, \mathrm{H}_{2} \mathrm{MoO}_{4} \cdot \mathrm{H}_{2} \mathrm{O}-0.02$. In the appropriate variant, $0.1 \%$ glucose was added to the mediums. The basic cultures grew on nitrate mediums, without glucose.

The composition of the ammonium medium was chosen after testing 8 preliminary variants which depended on substitution of the cations accompanying the anion $\mathrm{NO}_{3}{ }^{-}$and on buffering the medium. The chosen variant was shown to be relatively the most favourable in autotrophic cultures.

The algae were grown in the experimental cultures for about 3 weeks. Every few days part of the cultures was liguidated in order to perform the analyses. The cultures were kept in a photothermostat room at a temperature of about $24 \mathrm{C}$. In the variants with illumination, lighting was given constantly at an intensity of about $7000 \mathrm{~lx}$ (approx. $10 \mathrm{~W} \cdot \mathrm{m}^{-2}$ ). This is for autotrophic (without glucose) and mixotrophic (with glucose) cultures. Fluorescence lamps (tubes) were used. Heterotrophic cultures were grown with the addition of glucose, in the dark. 
Inoculations were done by introducing into $25 \mathrm{~cm}^{3}$ of medium in a $100 \mathrm{~cm}^{3}$. Erlenmayer flask, $1 \mathrm{~cm}^{3}$ of a suspension of algae from a two week-old basic culture. Five replicates were used for each analysis during the culture.

The dry mass of the algae and their protein content were determined. Protein was determined using Lowry's methods as described by Mejbaum-Katzenellenbogen and Mochnacka (1968). More details on this subject can be found in an earlier paper (Gumiński et al. 1984).

The $\mathrm{pH}$ and redox potential of the mediums were determined electrometrically. Accepted as an indicator of the redox potential was the $\mathrm{rH}$ value calculated from the formula: $\mathrm{rH}=\frac{\mathrm{Eh}}{29}+2 \mathrm{pH}$, where $\mathrm{Eh}$ is the sum of the potentials of a smooth platinum electrode in respect to a calomel electrode and the standard potential of a calomel electrode in respect to a hydrogen one, expressed in milivolts with measurements done at room temperature. The initial $\mathrm{pH}$ of the medium was about $7, \mathrm{rH}$ about 28 .

When dry mass was determined, average deviations were calculated for 5 replicates.

\section{RESULTS}

\section{Chlorella pyrenoidosa}

In the culture grown in the light without glucose (autotrophy), dry mass increased much more in the nitrate medium than in the ammonium one, however, when glucose was added (mixotrophy), the situation was reversed; with that growth was much better in the medium with glucose. In the dark, where glucose was always added (heterotrophy), dry mass increased however, more in the medium with nitrate than in the one with ammonium. In the light, in mediums with glucose and either $\mathrm{NH}_{4}{ }^{+}$ or $\mathrm{NO}_{3}{ }^{-}$, the dry mass increased continuously to the end of culture, that is, until the 19th day. Without glucose, it increased until the end only in the presence of $\mathrm{NO}_{3}{ }^{-}$whereas in the case of $\mathrm{NH}_{4}{ }^{+}$, only until the 16th day. In the dark, both with $\mathrm{NO}_{3}{ }^{-}$and $\mathrm{NH}_{4}{ }^{+}$, increase in dry mass was found only until the 12 th day, after which its amount lessened (Fig. 1).

The protein content rose, as a rule, only until the 16th day of culture. Under conditions of autotrophy it increased more rapidly in the nitrate medium than in the ammonium one, however, at the end, it was higher in the latter. In the case of mixotrophy, the reverse was true. Under heterotrophic conditions, the protein yield was initially higher in the ammonium medium; in the later stages of culture, in the nitrate medium (Fig. 2).

The $\mathrm{pH}$ was maintained on a generally higher level in nitrate mediums than in ammonium ones and was lower in heterotrophic conditions than 


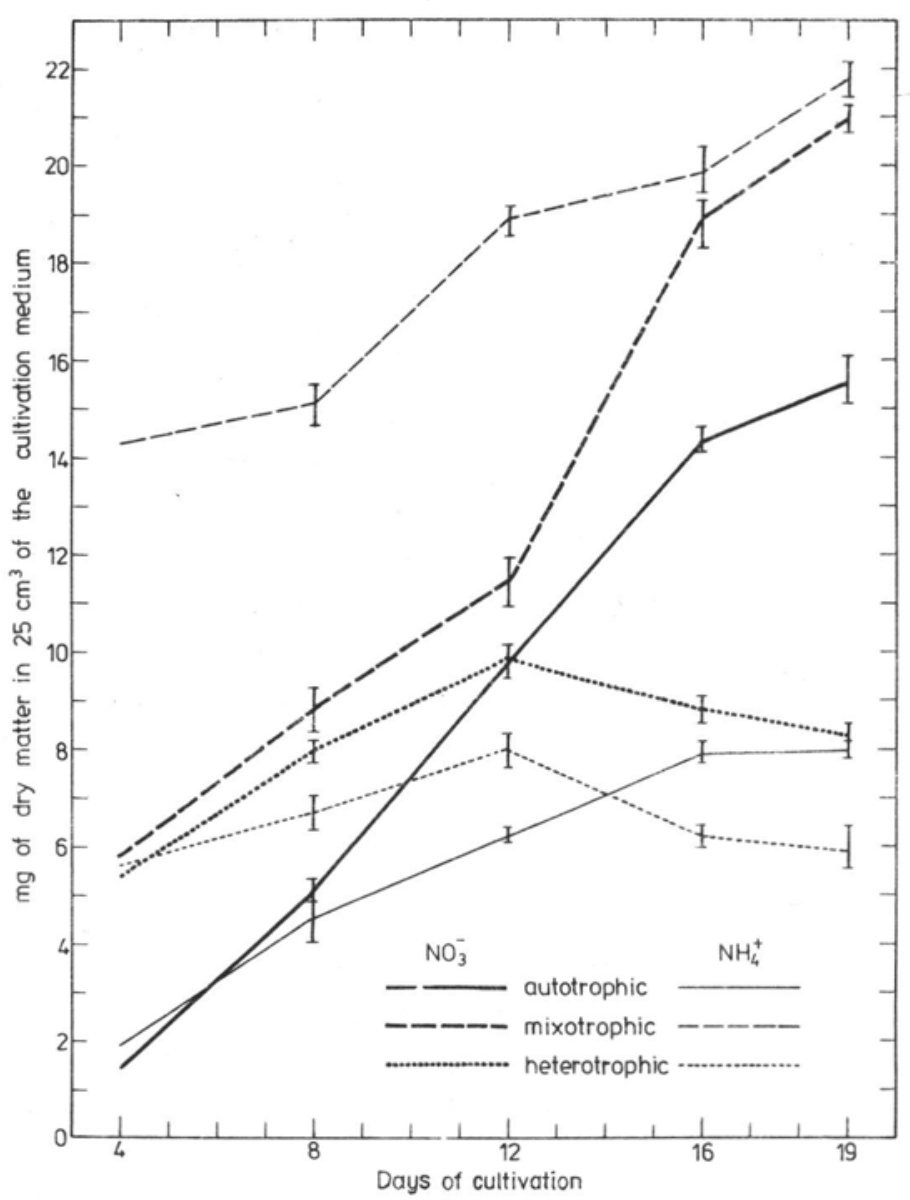

Fig. 1. Yield of dry mass in Chlorella pyrenoidosa cultures. Vertical bars denote the standard error

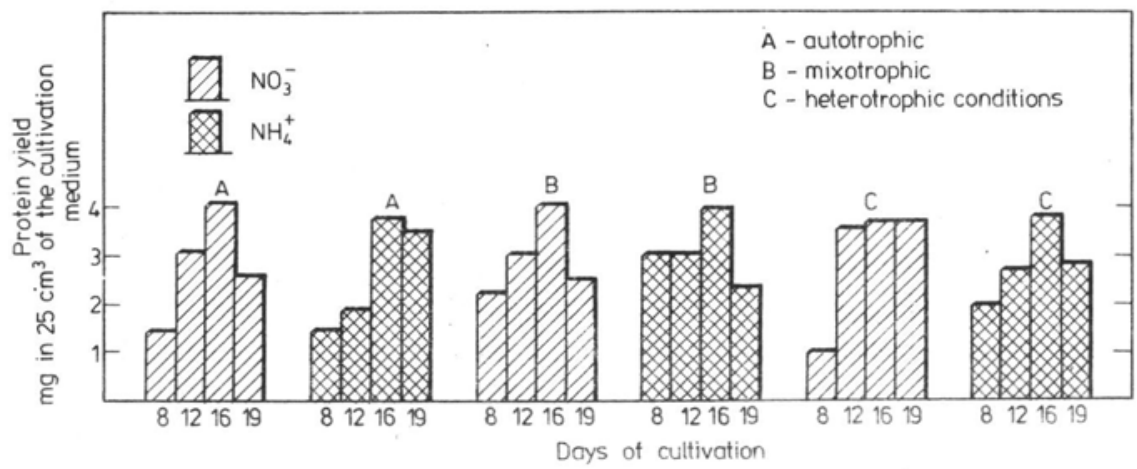

Fig. 2. Yield of protein in Chlorella pyrenoidosa cultures 
in auto- and mixotrophic ones. Decided acidification of the medium took place only under heterotrophic conditions in the presence of the ammonium form of nitrogen on the 8th day of the experiment. Generally speaking, the $\mathrm{pH}$ of the ammonium medium rose with time from slightly acidic to slightly alkaline (Table 2).

Table 2

Changes of $\mathrm{pH}$ and $\mathrm{rH}$ values Chlorella pyrenoidosa cultures

\begin{tabular}{|c|c|c|c|c|c|c|c|}
\hline \multirow{2}{*}{\multicolumn{2}{|c|}{ Type of medium }} & \multirow{3}{*}{$\begin{array}{c}\begin{array}{c}\text { Type of } \\
\text { measurement }\end{array} \\
\text { pH } \\
\text { rH }\end{array}$} & \multicolumn{5}{|c|}{ Days of cultivation } \\
\hline & & & 4 & 8 & 12 & 16 & 19 \\
\hline \multirow{2}{*}{$\begin{array}{l}\text { Auto- } \\
\text { trophic }\end{array}$} & $\mathrm{NO}_{3}{ }^{-}$ & & $\begin{array}{r}8.15 \\
28.48 \\
\end{array}$ & $\begin{array}{c}9.6 \\
29.53 \\
\end{array}$ & $\begin{array}{c}9.3 \\
29.82 \\
\end{array}$ & $\begin{array}{r}9.2 \\
30.3 \\
\end{array}$ & $\begin{array}{r}8.42 \\
30.52 \\
\end{array}$ \\
\hline & $\mathrm{NH}_{4}{ }^{+}$ & $\begin{array}{l}\mathrm{pH} \\
\mathrm{rH}\end{array}$ & $\begin{array}{r}6.83 \\
27.75 \\
\end{array}$ & $\begin{array}{c}7.2 \\
28.69\end{array}$ & $\begin{array}{c}6.9 \\
27.24 \\
\end{array}$ & $\begin{array}{c}6.9 \\
28.18 \\
\end{array}$ & $\begin{array}{r}7.25 \\
29.90 \\
\end{array}$ \\
\hline \multirow{2}{*}{$\begin{array}{l}\text { Mixo- } \\
\text { trophic }\end{array}$} & $\mathrm{NO}_{3}$ & $\begin{array}{l}\mathrm{pH} \\
\mathrm{rH}\end{array}$ & $\begin{array}{c}8.3 \\
30.32\end{array}$ & $\begin{array}{c}9.2 \\
31.12\end{array}$ & $\begin{array}{c}9.0 \\
29.90\end{array}$ & $\begin{array}{c}8.2 \\
30.43\end{array}$ & $\begin{array}{c}8.3 \\
30.63\end{array}$ \\
\hline & $\mathrm{NH}_{4}{ }^{+}$ & $\begin{array}{l}\mathrm{pH} \\
\mathrm{rH}\end{array}$ & $\begin{array}{r}6.63 \\
29.83 \\
\end{array}$ & $\begin{array}{c}6.8 \\
28.88 \\
\end{array}$ & $\begin{array}{c}6.7 \\
28.73 \\
\end{array}$ & $\begin{array}{c}7.4 \\
29.45 \\
\end{array}$ & $\begin{array}{r}7.77 \\
29.94 \\
\end{array}$ \\
\hline \multirow{2}{*}{$\begin{array}{l}\text { Hetero- } \\
\text { trophic }\end{array}$} & $\mathrm{NO}_{3}{ }^{-}$ & $\begin{array}{l}\mathrm{pH} \\
\mathrm{rH}\end{array}$ & $\begin{array}{c}6.7 \\
29.53 \\
\end{array}$ & $\begin{array}{c}7.5 \\
29.25 \\
\end{array}$ & $\begin{array}{c}8.2 \\
30.70 \\
\end{array}$ & $\begin{array}{c}8.2 \\
30.64 \\
\end{array}$ & $\begin{array}{r}8.45 \\
31.19 \\
\end{array}$ \\
\hline & $\mathrm{NH}_{4}{ }^{+}$ & $\begin{array}{l}\mathrm{pH} \\
\mathrm{rH}\end{array}$ & $\begin{array}{r}6.33 \\
28.11 \\
\end{array}$ & $\begin{array}{c}4.8 \\
24.68\end{array}$ & $\begin{array}{c}5.5 \\
27.01\end{array}$ & $\begin{array}{c}6.9 \\
30.16\end{array}$ & $\begin{array}{r}7.65 \\
30.36\end{array}$ \\
\hline
\end{tabular}

The $\mathrm{rH}$ values was as a rule higher in nitrate mediums than in ammonium ones. In the case of heterotrophy, in the latter mediums, this value fell on the 8th day of culture by about 4 units; on this same day, as was already mentioned, decided acidification in these same mediums was also found. Aside from this, the $\mathrm{rH}$ value either rose with time or remained on the same level in both the nitrate and ammonium mediums (Table 2).

\section{Scenedesmus quadricauda}

The effect of the studied experimental factors on the increase of dry mass in Scenedesmus was similar as in Chlorella. However, under heterotrophic conditions, the increases in biomass in both nitrate and ammonium mediums were equivalent (Fig. 3).

Increases in protein were slightly higher in the nitrate medium than in the ammonium one in all three variants, that is, under auto-, mixoand heterotrophic conditions (Fig. 4). The highest amount of protein was usually found on the 16th day of culture. 


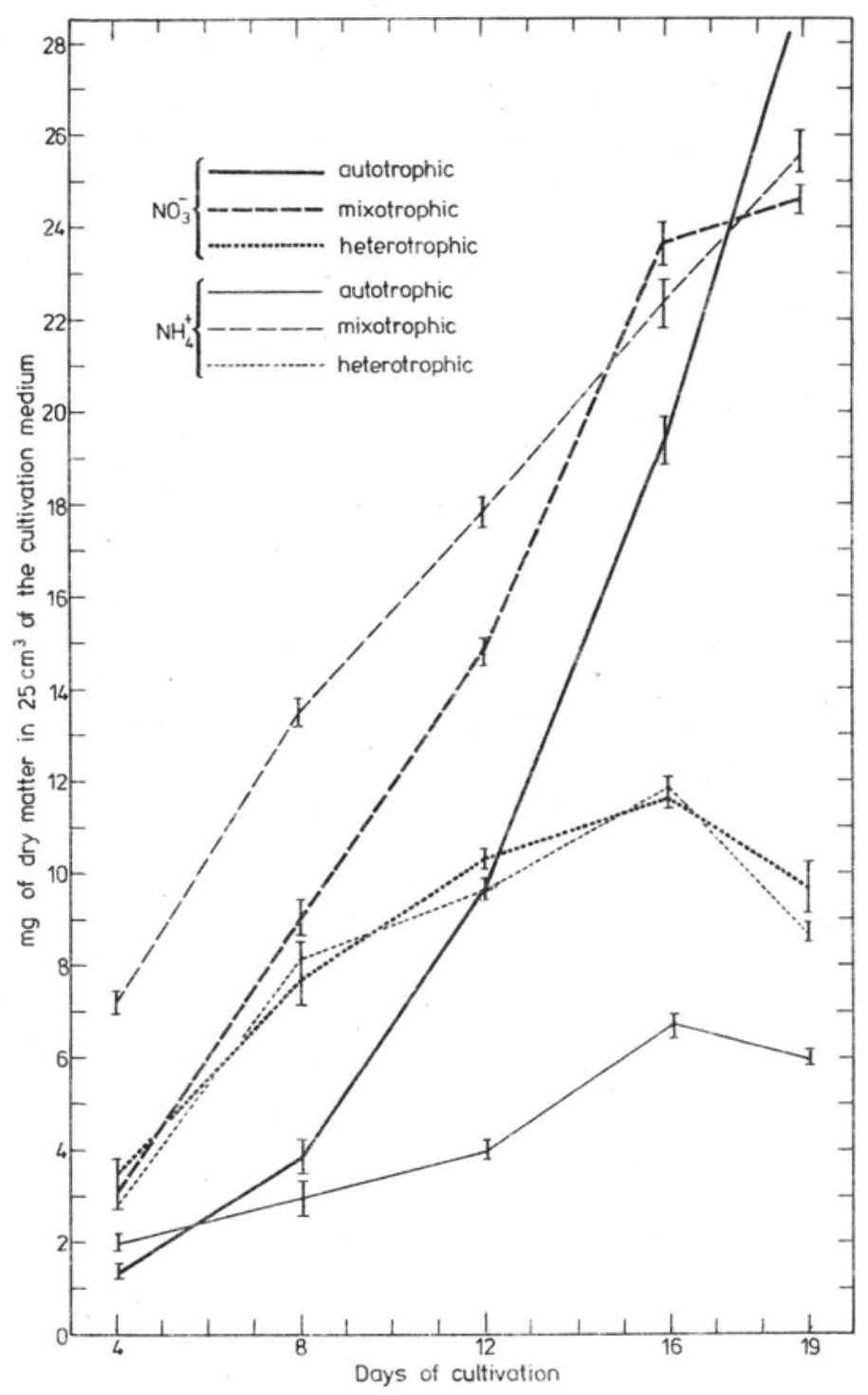

Fig. 3. Yield of dry mass in Scenedesmus quadricauda cultures. Vertical bars denote the standard error

The $\mathrm{pH}$ in the appropriate experimental variants was usually higher in the nitrate mediums than in the ammonium ones. Changes in the redox potential did not show a definite tendency. As in Chlorella cultures, a drop in the $\mathrm{rH}$ potential in the ammonium medium under heterotrophic conditions was found; however, in Scenedesmus ones, it took place more clearly after 4 rather than 8 days of culture. In addition, this phenomenon also took place after 16 days culture in the case of autotrophy (Table 3). 


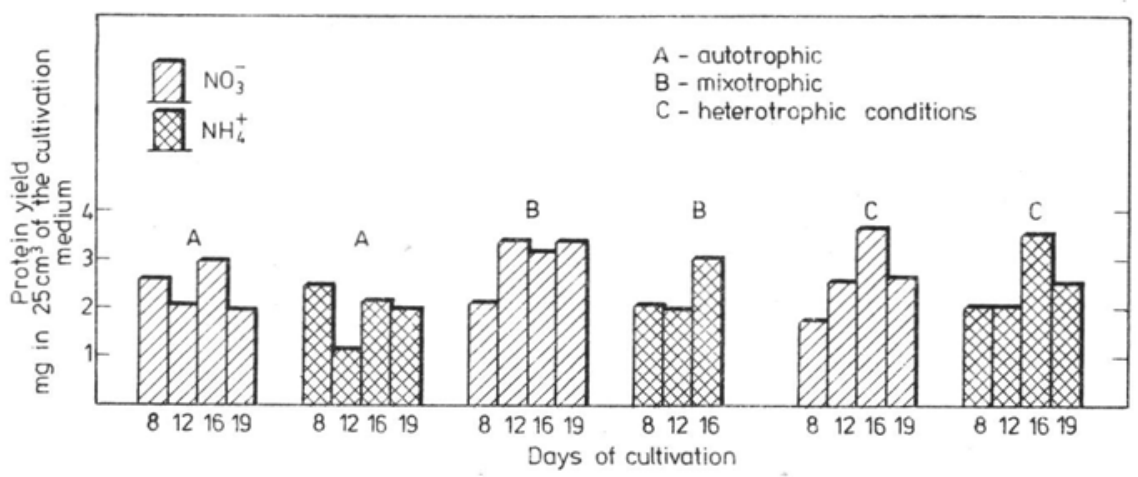

Fig. 4. Yield of protein in Scenedesmus quadricauda cultures

Table 3

Changes of $\mathrm{pH}$ and $\mathrm{rH}$ values in cultures of Scenedesmus quadricauda

\begin{tabular}{|c|c|c|c|c|c|c|c|}
\hline \multirow{2}{*}{\multicolumn{2}{|c|}{ Type of medium }} & \multirow{3}{*}{$\begin{array}{c}\begin{array}{c}\text { Type of } \\
\text { measurement }\end{array} \\
\mathrm{pH} \\
\mathrm{rH}\end{array}$} & \multicolumn{5}{|c|}{ Days of cultivation } \\
\hline & & & 4 & 8 & 12 & 16 & 19 \\
\hline \multirow{2}{*}{$\begin{array}{l}\text { Auto- } \\
\text { trophic }\end{array}$} & $\mathrm{NO}_{3}{ }^{-}$ & & $\begin{array}{r}7.66 \\
29.08\end{array}$ & $\begin{array}{c}9.4 \\
30.12\end{array}$ & $\begin{array}{c}9.4 \\
30.02\end{array}$ & $\begin{array}{c}9.5 \\
30.56\end{array}$ & $\begin{array}{r}9.06 \\
30.48\end{array}$ \\
\hline & $\mathrm{NH}_{4}{ }^{+}$ & $\begin{array}{l}\mathrm{pH} \\
\mathrm{rH}\end{array}$ & $\begin{array}{c}7.2 \\
28.49\end{array}$ & $\begin{array}{c}7.5 \\
29.42\end{array}$ & $\begin{array}{c}7.4 \\
28.16\end{array}$ & $\begin{array}{c}7.3 \\
26.50\end{array}$ & $\begin{array}{r}7.65 \\
29.44\end{array}$ \\
\hline \multirow{2}{*}{$\begin{array}{l}\text { Mixo- } \\
\text { trophic }\end{array}$} & $\mathrm{NO}_{3}{ }^{-}$ & $\begin{array}{l}\mathrm{pH} \\
\mathrm{rH}\end{array}$ & $\begin{array}{r}8.83 \\
31.41\end{array}$ & $\begin{array}{c}9.5 \\
30.01\end{array}$ & $\begin{array}{c}8.3 \\
30.50\end{array}$ & $\begin{array}{c}9.0 \\
30.43\end{array}$ & $\begin{array}{c}8.5 \\
31.16\end{array}$ \\
\hline & $\mathrm{NH}_{4}{ }^{+}$ & $\begin{array}{l}\mathrm{pH} \\
\mathrm{rH}\end{array}$ & $\begin{array}{c}6.9 \\
29.11\end{array}$ & $\begin{array}{c}8.2 \\
30.12\end{array}$ & $\begin{array}{c}8.6 \\
29.45\end{array}$ & $\begin{array}{c}9.1 \\
31.40\end{array}$ & $\begin{array}{c}7.1 \\
30.23\end{array}$ \\
\hline \multirow{2}{*}{$\begin{array}{l}\text { Hetero- } \\
\text { trophic }\end{array}$} & $\mathrm{NO}_{3}{ }^{-}$ & $\begin{array}{l}\mathrm{pH} \\
\mathrm{rH}\end{array}$ & $\begin{array}{c}6.7 \\
29.53\end{array}$ & $\begin{array}{c}7.3 \\
28.17\end{array}$ & $\begin{array}{c}7.7 \\
29.70\end{array}$ & $\begin{array}{c}8.3 \\
30.64\end{array}$ & $\begin{array}{r}8.28 \\
30.24\end{array}$ \\
\hline & $\mathrm{NH}_{4}{ }^{+}$ & $\begin{array}{l}\mathrm{pH} \\
\mathrm{rH}\end{array}$ & $\begin{array}{c}7.0 \\
26.24\end{array}$ & $\begin{array}{c}7.2 \\
28.49\end{array}$ & $\begin{array}{c}7.3 \\
29.93\end{array}$ & $\begin{array}{c}7.3 \\
32.61\end{array}$ & $\begin{array}{c}7.6 \\
30.83\end{array}$ \\
\hline
\end{tabular}

\section{Ankistrodesmus acicularis}

The increase in dry mass under conditions of autotrophy was higher in the nitrate medium than in the ammonium one (as in the previous two species). In the case of mixotrophy, the increase in dry mass dominated initially in the ammonium medium. However, after 12 days, the production of dry mass in the ammonium medium stopped and was equal in both the ammonium and nitrate variants. As a result, at the end of culture, the largest dry mass was found under autotrophic conditions in the nitrate medium. In the case of heterotrophy, the highest increase in dry mass was shown by the ammonium variant (Fig. 5). The increase in protein 


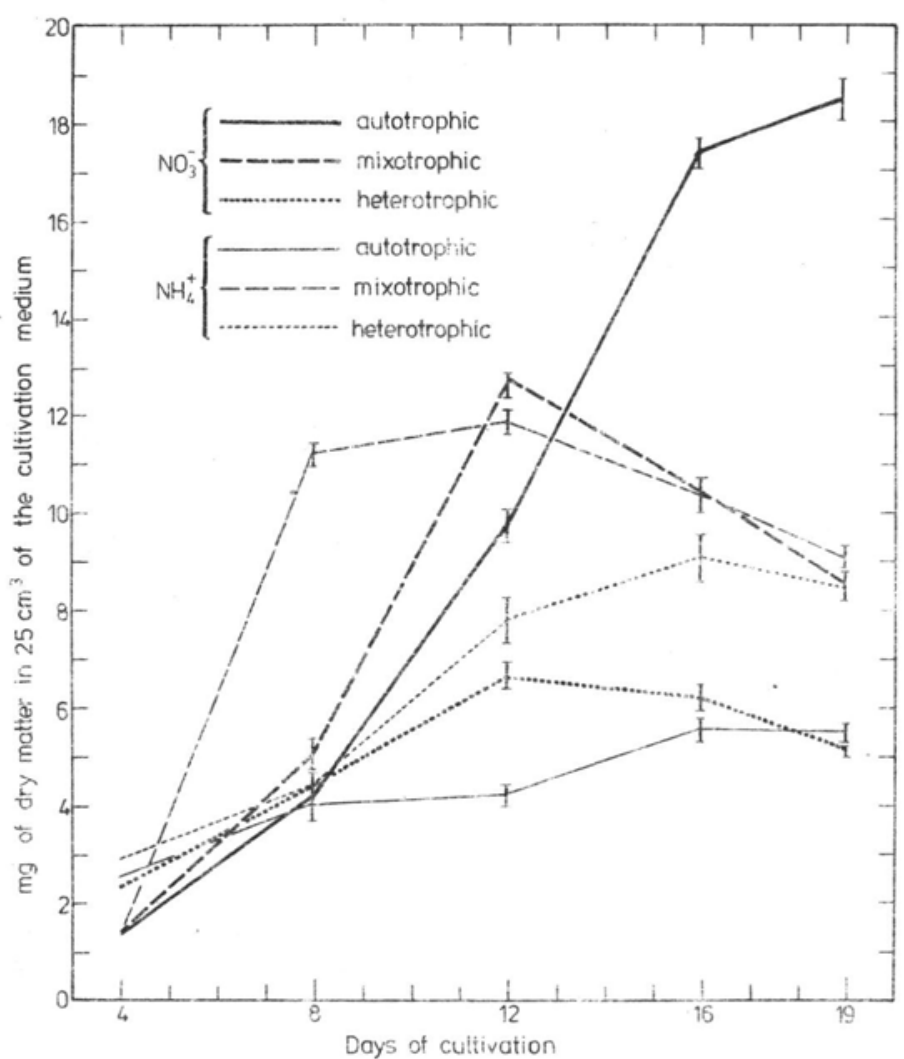

Fig. 5. Yield of dry mass in Ankistrodesmus acicularis cultures. Vertical bats denote the standard error

in the autotrophic variant was higher in the nitrate than in the ammonium medium. In the case of mixotrophy and heterotrophy these differences dissappeared. The maximum amounts of protein in the individual variants fell on different days culture (Fig. 6).

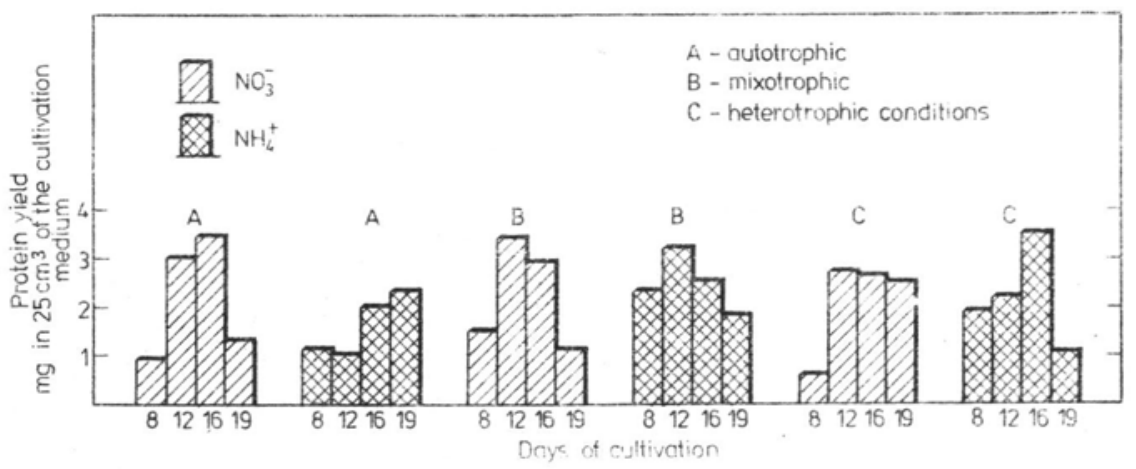

Fig. 6. Yield of protein in Anhistrodesmus acicularis cultures 
The $\mathrm{pH}$ value in the appropriate variants (auto-, mixo- and heterotrophic) was higher in the nitrate mediums than ammonium ones.

The $\mathrm{rH}$ value was maintained on a higher level in the nitrate variants than in the ammonium ones, similarly as was found with the two previous species. However, in Ankistrodesmus a fall in the $\mathrm{pH}$ and $\mathrm{rH}$ values in the initial stages of culture under heterotrophic conditions did not take place as had been found in Chlorella and Scenedesmus cultures (Table 4).

\section{Table 4}

Changes of $\mathrm{pH}$ and $\mathrm{rH}$ values in cultures of Ankistrodesmus acicularis

\begin{tabular}{|c|c|c|c|c|c|c|c|}
\hline \multirow{2}{*}{\multicolumn{2}{|c|}{ Type of medium }} & \multirow{3}{*}{$\begin{array}{c}\begin{array}{c}\text { Type of } \\
\text { measurement }\end{array} \\
\begin{array}{c}\mathrm{pH} \\
\mathrm{rH}\end{array}\end{array}$} & \multicolumn{5}{|c|}{ Days of cultivation } \\
\hline & & & \multirow{2}{*}{$\begin{array}{c}4 \\
7.6 \\
28.49\end{array}$} & \multirow{2}{*}{$\begin{array}{c}8 \\
9.4 \\
29.98\end{array}$} & \multirow{2}{*}{ 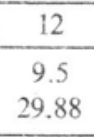 } & \multirow{2}{*}{$\begin{array}{c}16 \\
9.4 \\
30.02\end{array}$} & \multirow{2}{*}{$\begin{array}{r}19 \\
9.06 \\
30.43 \\
\end{array}$} \\
\hline Auto- & $\mathrm{NO}_{3}{ }^{-}$ & & & & & & \\
\hline trophic & $\mathrm{NH}_{4}{ }^{+}$ & $\begin{array}{l}\mathrm{pH} \\
\mathrm{rH}\end{array}$ & $\begin{array}{c}7.0 \\
28.09 \\
\end{array}$ & $\begin{array}{c}7.3 \\
27.66\end{array}$ & $\begin{array}{c}7.0 \\
27.82 \\
\end{array}$ & $\begin{array}{c}7.2 \\
29.04 \\
\end{array}$ & $\begin{array}{r}7.65 \\
29.67 \\
\end{array}$ \\
\hline \multirow{2}{*}{$\begin{array}{l}\text { Mixo- } \\
\text { trophic }\end{array}$} & $\mathrm{NO}_{3}{ }^{-}$ & $\begin{array}{l}\mathrm{pH} \\
\mathrm{rH}\end{array}$ & $\begin{array}{c}6.5 \\
30.14 \\
\end{array}$ & $\begin{array}{c}7.0 \\
28.84\end{array}$ & $\begin{array}{c}7.5 \\
28.96\end{array}$ & $\begin{array}{c}8.2 \\
30.40\end{array}$ & $\begin{array}{c}8.5 \\
30.68\end{array}$ \\
\hline & $\mathrm{NH}_{4}{ }^{+}$ & $\begin{array}{l}\mathrm{pH} \\
\mathrm{rH}\end{array}$ & $\begin{array}{r}68 \\
28.71 \\
\end{array}$ & $\begin{array}{c}6.7 \\
28.68 \\
\end{array}$ & $\begin{array}{r}7.1 \\
29.51 \\
\end{array}$ & $\begin{array}{c}7.1 \\
30.23 \\
\end{array}$ & $\begin{array}{c}7.1 \\
27.88 \\
\end{array}$ \\
\hline \multirow{2}{*}{$\begin{array}{l}\text { Hetero- } \\
\text { trophic }\end{array}$} & $\mathrm{NO}_{3}$ & $\begin{array}{l}\mathrm{pH} \\
\mathrm{rH}\end{array}$ & $\begin{array}{c}6.6 \\
29.60 \\
\end{array}$ & $\begin{array}{c}7.1 \\
29.14 \\
\end{array}$ & $\begin{array}{c}7.6 \\
30.19 \\
\end{array}$ & $\begin{array}{c}8.3 \\
30.64 \\
\end{array}$ & $\begin{array}{c}8.3 \\
29.90 \\
\end{array}$ \\
\hline & $\mathrm{NH}_{4}^{+}$ & $\begin{array}{l}\mathrm{pH} \\
\mathrm{rH}\end{array}$ & $\begin{array}{c}6.8 \\
28.71\end{array}$ & $\begin{array}{c}7.3 \\
28.85\end{array}$ & $\begin{array}{c}6.9 \\
29.33\end{array}$ & $\begin{array}{c}7.1 \\
30.30\end{array}$ & $\begin{array}{c}7.6 \\
30.43\end{array}$ \\
\hline
\end{tabular}

\section{DISCUSSION}

It was already known from previous studies (Gumiński et al. 1983) that all of the three studied species when feeding only artotrophically, grow better on mediums containing the nitrate form of nitrogen rather than the ammonium form. Presently, we have found that under the conditions of mixotrophy and heterotrophy (in the presence of exogenous glucose) the increase in dry mass can be much higher in the ammonium medium than in the nitrate one. On the basis of literature (Syrett 1962, Morris 1974) this can be explained in the following manner. First of all, exogenous glucose can prevent poisoning by excess of ammonia, secondly, an orginism uses much less energy to assimilate ammonia than nitrate. It would seem that in our case, the eventual consequences of physiological acidity of ammonium sulfate were successfully prevented by buifering the medium. However, under conditions of autotrophy, and in the case of Chlorella, also of heterotrophy (in the presence of exogenous glucose) the nitrate 
variant dominated in the production of dry mass over the ammonium variant. The superiority of the nitrate over the ammonium form not only under conditions of autotrophy but also of heterotrophy in Chlorella is cause for thought and leads us to treat this organism as clearly nitratephilic or ammoniumphobic.

Mixotrophy gave better conditions than auto- or heterotrophy, and therefore the quickest increase in dry mass under mixotrophic conditions was what was expected. Also the dominance of the ammonium variant over the nitrate one in mixotrophy is not surprizing.

Increase in protein under autotrophic conditions lasted for a shorter period than the increase in total dry weight, from which we can conclude that the multiplication of cells stopped sonner than the production of non-protein biomass. This would be in agreement with the results of Kyc (1970) who studied both cell multiplication and increase in dry mass of Scenedesmus quadricauda in autotrophic cultures. In the case of heterotrophy we did not observe such a phenomenon; in the case of mixotrophy the situation was unclear. It seems that two factors at the same time play an important role here: light and exogenous glucose.

The drop in dry mass from the 12th or 16th day of culture under heterotrophic conditions which was observed in all three species, and in Ankistrodesmus acicularis also under mixotrophic conditions, indicates the prevalence of catabolism over anabolism in the later phases of culture. This phenomenon also took place in relation to protein although with a certain shift in time. The drop in biomass at the end of culture could have been caused by either exhaustion of nutrients or by the accumulation of harmful metabolic products.

The lowering of the $\mathrm{pH}$ of the ammonium medium by the plants growing on it is a well known and understood fact. In order to prevent this negative phenomenon, we buffered the medium which in practice did not allow it to be permanently acidified. But the finding of a lower redox potential in the ammonium mediums than in the nitrate ones during the culture of the algae is something new and indicates the biological reduction of the environment when the ammonium ion is utilized. This phenomenon was clearly visible in Chlorella and Scenedesmus cultures, less clearly in Ankistrodesmus ones. This organism, however, showed the lowest increase in biomass and may be this is the reason this phenomenon was not so distinct as in the case of the other two species. The relatively parallel lowering of the $\mathrm{pH}$ and $\mathrm{rH}$ of the ammonium medium allows the assumption to be made that in both cases it is connected with the secretion of hydrogen cations in exchange for ammonium cation uptake. It is known that the acidification of the environment favours its reduction or, eventually, hinders its oxidation. 
It remains questionable whether the $\mathrm{rH}$ value is the appropriate measure of the redox potential of the medium in which algae are cultivated. However, since Eh measurements in solutions of variable $\mathrm{pH}$ cannot be accepted as an objective estimation of the redox potential of that solution, and $\mathrm{pH}$ changes of the medium during cultivation of algae are inevitable, in spite of everything, we accepted $\mathrm{rH}$ as a better indicat or of the medium's redox potential.

\section{Acknowledgments}

We are indebted to Dr. M. Baslerová and Dr. J. Dvoŕaková for sendings us the pure cultures of Chlorella pyrenoidosa, Scenedesmus quadricauda and Ankistrodesmus acicularis from the Store of Algological Cultures of the Czechoslovak Academy of Sciences.

This study was supported through the MR II/7 problem.

\section{REFERENCES}

Gumiński S., Jurajda K., Tatkowska E., 1983. The influence of the redox potential of the medium on the growth of some Chlorophyceae. Oceanologia 17: 29-32.

Gumiński S.. Jurajda K.. Tatkowska E.. 1984. Influence of reducing and oxidizing compounds and of the redox potential of the medium on the biomass of Scenedesmus quadricauda (Turp) Bréb. Acta Soc. Bot. Pol. 53: 223-235.

Kyć St., 1970. Próba wyjaśnienia mechanizmu działania humianu sodowego na przyrost ilości komórek i suchej masy Scenedesmus quadricauda (Trup) Bréb. Acta Soc. Bot. Pol. 39: 681-700.

Mejbaum-Katzenellenbogen W., Mochnacka I., 1968. Kurs praktyczny z biochemii. PWN, Warszawa.

Morris J., 1974. Nitrogen assimilation and protein synthesis. In: Algal Physiology and Biochemistry. Stewart W.P.D. (ed.). Blackwell Scientific Publications, Oxford-London-Edinburgh-Melbourne. pp. 583-609.

Syrett P. J. 1962. Nitrogen Assimilation. In: Physiology and Biochemistry of Algae. Lewin R. A. (ed). Acad. Press, New York-London. pp. 171-188.

Uspenski E. E., 1927. Eisen als Faktor für die Verbreitung niederer Wasserpflanzen. Pflanzenforschung (Jena) 9: 1-104.

Przyrost biomasy wybranych gatunków zielenic w pożywce azotanowej lub amonowej w zależności od warunków auto-, mikso- czy heterotroficznych

\section{Streszczenie}

Badano przyrost całkowitej suchej masy i białka roślin w kulturach Chlorella pyrenoidosa, Scenedesmus quadricauda i Ankistrodesmus acicularis. Sucha masa przyrastała najsilniej w warunkach miksotroficznych, słabiej w przypadku autotrofii $\mathrm{i}$ o wiele słabiej w wariancie heterotroficznym. Nie stwierdzono jednoznacznych różnic w przyroście białek. W przypadku autotrofii ilości suchej masy były znacznie większe w pożywce azotanowej niż w amonowej, 
w warunkach miksotrofii było odwrotnie a w warunkach heterotroficznych poszczególne gatunki reagowały niejednakowo. Przyrosty białka nie wykazywały określonych różnic w zależności od azotanowej czy amonowej formy pożywki. Przyrost białka w warunkach auto- i miksotroficznych trwał na ogół krócej niż przyrost całkowitej suchej masy. Odczyn kwasowo-zasadowy utrzymywał się $\mathrm{w}$ pożywce amonowej na niższym poziomie niż $w$ odpowiednich wariantach doświadczalnych ẃ pożywce azotanowej. Podobnie potencjał redox pożywki amonowej był w odpowiednich wariantach doświadczainych niższy niż azotanowej. 